Review paper UDC 165.745(045)Ortega y Gasset, J.

doi: $10.21464 / \mathrm{sp} 32210$

Received: December 22, 2016

\author{
Tomislav Krznar \\ University of Zagreb, Faculty of Teachers Education, Savska cesta 77, HR-10000 Zagreb \\ tomislav.krznar@ufzg.hr
}

\title{
Remarks on Understanding Phenomenon of Life in the Philosophy of José Ortega y Gasset
}

\begin{abstract}
In this paper we are trying to point out possibilities for a bioethical reading of thoughts of Spanish philosopher José Ortega y Gasset. The key problem which we are trying to expose is Ortega's understanding of the phenomenon of life and in this respect we especially focus on his work El tema de nuestro tiempo (1923). Ortega y Gasset argues that Western way of thinking may be leading humanity to its mental collapse because it does not provide full comprehension of human existence, rather, it is stressing only one dimension, the rational one, reductively. The central position of this work, created through an understanding of the philosophy of Ortega y Gasset, is the understanding of life as an existential whole, which presuposses the imperative of building a new type of knowledge, that knowledge which is focused on the care and preservation. Ortega y Gasset argues that human life is a radical reality, and bioethical reading of his thoughts points us to the conclusion that life must no longer be understood as a resource, but as a whole that needs to be preserved.
\end{abstract}

\section{Keywords}

José Ortega y Gasset, philosophy, life, integrative thinking, bioethics

The purpose of this paper ${ }^{1}$ is to point out possibilities for the bioethical reading of thoughts of Spanish philosopher José Ortega y Gasset (1883-1955). A key problem that we are trying to expose is Ortega's understanding of phenomenon of life, and in this respect we especially focus on Ortega's monograph $E l$ tema de nuestro tiempo (1923) in which, according to many interpreters of his thought, Ortega y Gasset begins the construction of the most important parts of his philosophy, the concept of ratiovitalism.

We will try to think from Ortega's point of view about some cultural challenges, especially growth and specialization of scientific knowledge, the scientification of culture, and turning all life into a technological event. Even a superficial look at the philosophy of Ortega y Gasset indicates numerous highly indicative insights that this philosopher had shaped. In this regard, we will try to look at Ortega's thought as an incentive for integrative understanding of human life, more precisely the type of thinking that tends to preserve

1

Research presented in this paper was part of the project "Formation of the concept of ratiovitalism in the philosophy of Ortega $y$ Gasset", no. HP 1.7, led by Tomislav Krznar, and financed by the University of Zagreb in 2014. This paper was written as a part of the research program of Centre of Excellence for
Integrative Bioethics (declared on November 10, 2014 by Ministry of Science, Education and Sport of the Republic of Croatia), which is being realized at the Faculty of Humanities and Social Sciences of the University of Zagreb. 
the sense of human existence through the preservation of all segments and the characteristics of life. That is the message Ortega's philosophy significantly inspires in a rethinking of the problem facing modern humanity. Ortega y Gasset says that this is so because the human life is a radical reality, something that has to be designed, and should be designed in association with the whole of existence, and the most important part of existence is the life itself.

We need to sketch the interpretation of two concepts that Ortega y Gasset used. The first is the concept of integrativity and the other is concept of bioethics. Through both of these terms we refer to the concept of integrative bioethics, which seeks to explain some of the most pressing problems of modern human, and gives useful tools for providing the solution to these problems (Jurić, 2012; Krznar, 2012). In this regard, the "integrative" is understood as an effort to include the opinion of the wholeness of some problem by looking at it from different aspects and perspectives, while the term "bioethics" is understood as an elaborated theory which is essentially directed towards action having in mind the whole of life, and the imperative of its preservation. Both terms are actually a result of efforts to create a new horizon of human existence. In this regard we read Ortega y Gasset, one of its parts in particular.

\section{Why is there a philosophy?}

This is probably one of the most difficult philosophical questions (Krznar, 2016) present in every philosophical thinking, and through any effort aimed at making life meaningful (Krznar, 2014). It seems appropriate to note that Ortega y Gasset devoted a significant part of his creative energy to a search for an answer to this question. Following Ortega y Gasset's thought, in layers of problems of this issue we would like to show that philosophy is what gives human beings the possibility of orientation in their own life, to understand the orientation as taking care of his own living environment, both in the humanistic, as well as cultural and biological terms (Gray, 1989). Let us look at two aspects of the problem, namely the two definitions of philosophy, as seen by Ortega y Gasset.

Philosophy can be considered as a firm and relevant answer to the questions of our existence, it is a set of reliable knowledge about our world, and at the same time the confirmation of building oneself up. This is because, Ortega writes,

"... and in pure truth, only the idea-producing, the thinking, the conscious exists; I, I myself, me ipsum." (Ortega y Gasset, 1960:160)

There is "some I" who asks about oneself. This question is an essential for defining "that I", and at the same time "that I" has a task to find oneself through that question. Now we get into position from which we can ask another question: what does some specific philosophy have to do with this "I"? It is, as Ortega would say, our obligation to find ourselves, and come up with our authentic life (Krznar, 2016). The term "authentic" should be understood as one that is made in their own efforts, contrary to intense pressures from outside. In this respect Ortega can truly say:

"... the root and heart of living consist of knowing oneself and understanding oneself, of observing oneself and what surrounds one, of being transparent to oneself." (Ortega y Gasset, 1960:217)

In the core of the problem of philosophy, there is a reflection deliberately plunged into the depths of our own existence, with the obligation of building a genuine "I". Of course, there is a shadow cast over these efforts, there is something in human existence, and in life in general, that opposes the suc- 
cessful completion of these tasks, retrieving authentic "self". Here, in fact, we find indications of what Ortega y Gasset called radical reality (Gonzales, 2005). We can say that the philosophy is nothing more than a note left by the paradox of human existence, and that the existence is yet to be shaped if we want to call it human. Task of the reflection on this effort was entrusted to philosophy, and Ortega boldly states that all

“... which does not define philosophy as philosophizing, and philosophizing as an essential type of life, is neither sufficient nor basic." (Ortega y Gasset, 1960:240).

But let us look at another definition of philosophy, at Ortega's understanding of the job of the philosopher that has to light up trials on intellectual charity (Ortega y Gasset, 1961:31), and take away the darkness of intellectual environment in which we live. That is possible only through knowledge of its circumstances, and by gathering perspectives that make up this fact. It is necessary, says Ortega y Gasset, to closely connect with the environment in which we operate, to understand it, and to love it, and by the efforts of this to change it. The separation is destruction (Ortega y Gasset, 1961:33), and philosophy is

“... general science of love; it represents the greatest impulse toward an integrated whole within the intellectual sphere, with the result that a shade of difference between understanding and mere knowing become apparent in it." (Ortega y Gasset, 1961:38)

Ortega y Gasset believed that business of philosophy is not to gather facts. It does not walk on the surface; it should rather dive into the depth of things (Krznar, 2014). Philosophy is pursuit of knowledge, of knowing the being, possibility of coming close to the essence of things, and this is precisely by the fact that it is a pure synthesis. In fact, he says, the last ambition of philosophy was to "arrive at single proposition which would express the whole truth". (Ortega y Gasset, 1961:39)

In short, says Ortega y Gasset, philosophy is the knowledge about the Universe (Ortega y Gasset, 1960: 60), and the Universe should be understood as the totality of existence, something that is comprehensive and unknown, and at the same time present and unreachable. The philosopher is doing his job when he embarks on a journey to the unknown as such, thus the Universe is, he says, indicated as what fundamentally we do not know, what we see "in any positive content as absolutely unknown" (Ortega y Gasset, 1960:61). When we say that philosophy is the knowledge about the Universe, it is necessary to say that knowledge is actually gradually approaching the ideal, so says Ortega y Gasset. Philosophy is understood as a comprehensive system of intellectual attitudes through which a tendency toward absolute knowledge is methodically being organized (Ortega y Gasset, 1960:63).

We are left to ask the important question: what is the result of these efforts, do we want to achieve the cognition of the Universe, or to illuminate the darkness around us? Here Ortega y Gasset gives unexpectedly direct response: knowledge. In his own words:

"So we must protect the meaning of the word knowledge, and note that if in effect it does mean primarily that full entrance into thinking about the Universe, there will be a scale of values for knowledge, depending on how close it comes to that ideal. Philosophy must begin by defining that maximum concept and at the same time must leave itself open to those lesser grades which in the last analysis will be another set of ways of knowing. For this reason, when I define philosophy as knowledge of the Universe I propose that we understand an integral system of intellectual attitudes in which the desire for absolute knowledge is organized methodically. In order that a complex of thoughts may be a philosophy, the decisive thing is that the reaction of the intellect to the Universe shall also be universal, integral in short, that it be a system which is absolute." (Ortega y Gasset, 1960:63) 
Finally, philosophy exists in order to achieve safe and confident knowledge that enables us guidance in life, in dealing with the human condition, and with the effects of our actions.

\section{The problems of life of contemporary human}

Before discussing the problem of life, it is necessary to consider the relationship of modern human to life, specifically to the whole of existence (Krznar, 2012:29). The technological capacities of modern human being, as a being whose existence is marked by a sense of superiority over all forms of life, and even more, a sense that all life forms exist as a means for human purposes, are truly frighteningly powerful. Today it is possible to transform the whole area of any landscape, split an atom or create new genetic code of living beings. Furthermore, it is possible, in a very short period of time, to communicate or even travel through planetary-size distances. It is possible to use existing natural structures of life to produce new ones, and use cultural patterns as models to facilitate these processes. Certainly, both activities produce a number of problems that manifest as ruthless exploitation of natural resources, emission of large amounts of harmful substances into the environment, the destruction of the existing social and cultural patterns, increasing poverty and the creation of global uncertainty. In the background of all these activities lays a certain type of knowledge that is based on the anthropocentric concept of human action, and forms the model of domination, exploitation, and efficiency maximizing. Of course, the whole of life or the protection of human dignity are excluded from these efforts (Krznar, 2012:33).

On the ground of this situation, we see three dimensions of the way of living of modern human being (Jurić, 2012). The first course of action, in terms of production, is the maximization of profit and relentless exploitation of capacity, natural resources and human labour, in order to achieve desired goals. Second type of knowledge is based on the supremacy of human mind in relation to the whole of life, as well as the account benefits, ongoing prudence, and restraint. Third is the relationship to the meaning of human existence, determent in fragmentation, usability and operability, and bears the mark of monoperspective understanding of truth. Monoperspectivity is a metaphysically founded belief that there is one truth and one way to it, the truth is the supremacy of human existence, and the road to it resembles a mechanical, numerical, and beneficial science that is formed through the modern experience of West. In this understanding of the world, life, as a whole, organic and inorganic existence, as well as cultural patterns formed on the basis of the relationship between human being and biological substratum of existence, is just a building block used to the commotion of human. Of course, we talk about one part of the human race (Men), one site (the West) and one economic class (Elite). In this respect we can use the instructive words of Hrvoje Jurić:

"A possible description of the source of these problems could be - the loss of the whole, the idea of the whole and the feeling of the whole, as well as the extreme fragmentation and specialization of the science and, consequently, of the education. In the time of fragmented science, it is more and more difficult to talk about the aims and the goals of science and education in the traditional sense, as well as about the related concepts of knowledge and truth." (Jurić, 2012:86)

Paradoxically, an indication of the destruction of many life phenomena, as well as numerous cultural patterns, resulted in numerous attempts of interpretation of these phenomena, as well as searching for the solutions for these problems. All efforts are marked with holistic approach, contrary to former 
fragmentary understanding of human existence, and are characterised by a new attitude towards life. It is understood that a new attitude towards life can be shaped only on the basis of a new way of understanding of life. If life, in different forms and manifestations, is no longer perceived as a material for human ends, but as a value in itself, something that is precious in the broadest possible spectrum of existence, then we have an obligation to build not only a new understanding of life, but also new social tools of preserving life (Jurić, 2015). Here we got above the ethical threshold. We must discern new forms, and for that reason it is now necessary to take a look at Ortega's understanding of the phenomenon of life.

\section{Life as an integrative phenomenon}

It is necessary to describe the understanding of the phenomena of life as it is outlined by Ortega y Gasset in the work of El tema de nuestro tiempo (1923). We rely primarily on this work because in it Ortega y Gasset diagnosed a certain state of affairs, in particular, on the one hand, the problems of rationalist understanding of human existence, and the vitality of the human being, on the other. By their commitment to a secure knowledge, Ortega y Gasset examines a character of philosophical systems and their essential explanation of their existence. In this respect, he reviews the problems of relativism and rationalism.

When it comes to relativism, Ortega y Gasset brings two significant objections: firstly, if the truth does not exist, then relativism cannot be taken seriously; Secondly, the belief that there is indeed an epistemological and ethical point of view, one of the most deeply rooted beliefs in human existence, and if it is taken away, it condemns human life to an illusion or absurdity.

"Relativism is, in the long run, scepticism, when its justification is that it opposes all speculative theory, is in self a theory of suicidal character." (Ortega y Gasset, 2012:29)

On the other hand, especially since the Renaissance, many people have created a powerful theory of rationalism, which is based on the belief that the truth is single, absolute and incorruptible and that it cannot be added to our individual existences. That belief causes, so says Ortega y Gasset, a schism in human being's personality, and that should be carefully addressed.

"On the one side stands everything vital and concrete in his being, his breathing and historical reality. On the other, that rational nucleus which enables us to attain truth, but which nevertheless has no life. It is an unreal phantom, gliding immutably through time, alien to vicissitudes which are a symptom of vitality." (Ortega y Gasset, 2012:30)

In this way, says Ortega y Gasset, rationalist thought is insufficiently successful because it cannot arrive to the inner corners of human existence. It recognizes only one dimension in respect to the pure rational retrieval. Particularly when it comes to the problem of life, Ortega y Gasset resolutely rejects the two theories:

"Neither rationalist absolutism, which keeps reason but annihilate life, nor relativism, which keeps life but dissolves reason, are possibilities.” (Ortega y Gasset, 2012:35)

We are left to wonder about two things: what theory can most successfully explain human life, and through what structure is that human life built? Ortega y Gasset brings up the explanation about multidimensionality of cultural existence. This is particularly interesting explanation Ortega y Gasset connects to the problem of truth that we have indicated previously, and he shows that 
the problem of "truth is dispersed throughout all the spiritual orders which we imply when we use the word "culture"" (Ortega y Gasset, 2012:37). This brings up one of the most important aspects of Ortega y Gasset's understanding of life:

"To understand a biological phenomenon is to demonstrate its necessity for the preservation of the individual, or, what is the same thing, to discover its vital utility. My thought, therefore, finds its cause and justification in myself as an organic individual: it is an instrument for the benefit of my life, an organ of it, regulated and governed by it." (Ortega y Gasset, 2012:38)

Ortega y Gasset explains that a human being is an organic being and mental act at the same time, and as such she has the ability to conceptualize her own existence and behaviour aimed towards the truth. When it comes to the phenomenon of life, Ortega y Gasset effectively concludes that life is something more than life; what is imminent and it is transcendence beyond vital limits (cf. Ortega y Gasset, 2012:41).

In other words, Ortega y Gasset thinks that culture holds life, it is the umbrella under which the biological and spiritual things are connected, and both must remain complete. Ortega y Gasset remarkably says:

"There is no culture without life, there is no spirituality without vitality in the most literal sense that the word can bear. The spiritual is not less or more life than the non-spiritual." (Ortega y Gasset, 2012:44)

It must not be forgotten that the spiritual and cultural functions are simultaneously biological functions (Ortega y Gasset, 2012:45), or better, what is human must be compatible with the wholeness of life. It is understood that here Ortega y Gasset is not advocating some form of return to the primordial state, some nativism or even primitivism, but neither emotivism, since reason is "merely a form and function of life", and culture is a "biological instrument and nothing more". (Ortega y Gasset, 2012:58). Ortega y Gasset sees a problem of Western history in the saturation of rational, predominant logical forms and in empty speculation. In this respect he determines the philosophy of his time through imperative of moving towards the vital mind. He calls this work the Theme of our times.

"The modern theme comprises the subjection of reason to vitality, its location within the biological scheme, and its surrender to spontaneity. In a few years it will seem ridiculous to have exacted from life acquiescence in the service of culture. The mission of the new age is, precisely, the conversion of that relation and the demonstration that it is culture, reason, art and ethics that must enter the service of life." (Ortega y Gasset, 2012:58)

Impresively, he say that pure "reason has, then, to surrender its authority to vital reason" (Ortega y Gasset, 2012:59). In this respect, he constructs a concept of vital values, but also shows that life "is cosmic realization of altruism" (Ortega y Gasset, 2012:73). More poetically:

"Life is like crystal, the transparent medium through which we can see other objects. If we permit ourselves to be deluded by the strong desire than any transparent thing implants in us, to pass needlessly through it to something on the other side, we shall never see the crystal. In order to reach the point of perceiving it we have to disregard everything behind the glass and bring our black to itself, to that ironical substance which seems to have a self-annihilating quality and to permit itself to be penetrated by what lies beyond it." (Ortega y Gasset, 2012:73)

To summarize: human being is a very complex set of different components. Ortega y Gasset argues that the Western way of thinking maybe leads humanity to mental collapse because it does not provide full comprehension of human existence. It stresses only one dimension - nothing beyond the rational 
- and this too reductively. Ortega's reflections on life are a foundation for building a new type of knowledge, because it allows orientation only in some person's life (Krznar, 2016). Arguing in favour of such approach, Ortega y Gasset developed its own concept in philosophy - ratiovitalism.

\section{What is ratiovitalism? Preliminarily determination}

In brief, let us now see a core characteristic of Ortega's philosophical concept of ratiovitalism.

This term is used in two meanings: as a phase in Ortega's life and work, and as inventive philosophical learning. F. Niedermayer says that from the second decade of the twentieth century onwards Ortega y Gasset is beginning to learn that philosophical lines of rationalism and idealism cannot explain the phenomenon of human life, which can be understood, as Ortega y Gasset considered, only as a radical reality (Niedermayer, 1973:52) since

“... only the facets of life that give reason to man and his circumstances and make them comprehensible. And, since life takes places in history, reason can only occur in history, not as an abstract, disembodied entity that is extratemporal and extraspatial." (Niedermayer, 1973:51)

This reveals us many layers of problems and the importance of understanding the needs for Ortega y Gasset's to shift towards a new understanding of the problems of life, as well as it reveals the problem of designing human existence. V. Ouimette properly notices that it was the work of El tema de nuestro tiempo where Ortega y Gasset warned that the main problem of his philosophy is that

“... while his concepts should not be understood as mere biologism, neither should they be seen as undermining the importance of reason. Rather, they were directed against rationalism as a philosophical dogmatism that aimed to cast the world in its own image." (Ouimette, 1982:92)

As Ortega y Gasset's phase, ratiovitalism lasted from 1924 to 1955, and it is a time of his most intense intellectual activity in which he made his most important works, beginning with the El tema, and until his posthumously published works. Faced with the shortcomings of the philosophy of idealism (Rodríguez Huéscar, 1995), especially with Kant's thought, and looking at the shortcomings in, then prevailing, philosophies that overemphasized biological or naturalistic aspects, Ortega y Gasset developed the following disposition: neither rationality nor vitalism (Ferrater Mora, 1957:38). There is a need to connect positive parts of the learning, and at the same time overcome and overturn their differences, but this effort Ortega y Gasset expressed in his metaphysics of vital reason or ratiovitalism. It is worth noting that this is a metaphysical understanding of a search for radical reality in which everything is rooted and from which each being draws its measure of reality. Therefore, we can say that the mind is a human life, and the reality of human existence may be understood only from the standpoint of life, when it focused on the comprehensiveness in which it is rooted. These positions are instructively described by J. Marías, with his interpretation of the relationship between key concepts of Ortega's philosophy:

“... circumstance and perspective are two relatively abstract concepts, in the sense that they are not sufficient, nor is their mutual reference sufficient. Both are aspects or ingredients, perhaps dimensions, of a higher reality from which they must be understood and which confers upon them the fullness of their meaning; they are, in their turn, instruments used by Ortega to achieve the intellectual apprehension of that reality with which, in principle, he does not find himself, precisely because he finds himself $i n$ it. This reality is human life - the expression used, for the moment and for the sake of clarity, in a slightly inaccurate manner." (Marías, 1970:380) 
It is a fact that he needed an umbrella term (Graham, 1994:318) that would "roof" his own thought efforts and allow him further consideration. He found that umbrella term in the issues regarding life, but it cannot be said that it was used uniformly. On the contrary, until the end of his life he sought precise and more powerful expression, but always the central position of these efforts was expressed in El tema: put all forms of human activities in the service of life. Ortega y Gasset tried to interpret many problems, such as the ontological, epistemological and social problems in this key (Ferrater Mora, 1957:46).

\section{Philosophy of Ortega y Gasset as inspiration of integrative thinking}

Let us try to shape the current debate on the issue of life by analysing the concept of life. Term "life" in the philosophy Ortega y Gasset can be understood in at least three meanings:

1 Life as a human life, as a form of existence that includes awareness, action, freedom of decision, selectable modes of existence and awareness of social reciprocity.

2 Life as a cultural structure, understood as a way of being, overflowing awareness of societal structure, the construction of beliefs and customs, building ethical standards and legal definitions, building stable social mechanisms, generating the mode of production, distribution and consumption of goods.

3 Life as a whole of being, physical and chemical understanding of metabolism and energy, biological understanding of the many ways of being and life forms, understanding the connection between these forms and ways of interaction, understanding the model of preservation or destruction of units and the creation of personal or social relationship with the whole of life.

Efforts to seek solutions to the problem, at least when it comes to philosophical efforts, especially when it comes to the need for construction of new thought and cultural patterns, are always getting out of sight in the similar efforts that were undertaken by numerous philosophers throughout history (Jurić, 2015; Sören Hoffmann, 2015). In this we try to find our own contemplative heritage, not only stronghold for personal search after solutions to problems, but also to create reliable and solid concepts which can be used in concrete human situation. Philosophy of Ortega y Gasset makes an excellent example of this, particularly because he recognizes the problems posed by the specialization of knowledge, technicisation of life, and problems of mass culture. Ortega y Gasset's thoughts show us the fragmentation of knowledge and reductive concepts of thinking that are at work in Western civilization. He noted that every great philosophy has its peak in the type of knowledge that seeks to explain life, but at the same time, he noted the important fact of the relationship of philosophy to the phenomenon of truth.

Ortega y Gasset criticized the understanding of truth as a fragmented and technical construct, which is a monoperspective understanding (Jurić, 2012:85) and it is facing the practical, useful purpose, only in raising the human conformity. Ortega's understanding of the phenomenon of life is going in a different direction. He advocates integrity, connection of all forms of existence, solidarity and commitment to maintain a whole, in contrast to the one-dimensional efforts. Ortega y Gasset argues that such form of culture can be said to be the bearer of life, and not its destroyer, as it is the case in Western 
civilization that we have seen to be based on the type of knowledge that is fragmentary and reductive. Ortega y Gasset argues for integrity and depth of understanding the connection of all forms of existence. Western understanding of human existence, and the type of knowledge on which this understanding is built upon, provokes the need for building a new type of knowledge, the integrative one. In Ortega's words:

"Knowledge is the acquisition of truths, and in acquiring truths we become acquainted with the transcendental or trans-subjective universe of reality. Truths are eternal, unique and invariable. How, then, can there be, in the knower, any process by which they can be identified? The replay of rationalism is narrow and arbitrary: knowledge is only possible if reality can penetrate in without the last disturbance of its own fabric. The knower, therefore, must be a transparent medium, lacking any sort of special quality or characteristic colour: he must be the same yesterday and to-day or to-morrow: he must therefore be ultra-vital and extra-historical. Life has essential characters of its own, it changes and develops: in word, it is history." (Ortega y Gasset, 2012:87)

We can say that Ortega's understanding of the phenomenon of life, especially from the viewpoint of the problems of Western civilization, is a desirable substrate for the construction of bioethical concepts. The effort of thinking about the character of human existence, social structure and cultural phenomenon that does bioethics (Jurić, 2015), especially in the form of integrative bioethics (Krznar, 2012) has its foundation in the imperative of building a new outlook on life, on life as a whole and reciprocity of numerous forms of existence. These positions generate the obligation of preserving the richness and beauty of existence as the possibility of preserving the human being in human form.

\section{Conclusion}

In this paper we tried to provide the beginning of deliberation about the philosophy of Ortega y Gasset from the viewpoint of a new understanding of human being and his role in the preservation of life which as a new course of action we see in the emerging field of bioethics, especially integrative bioethics. Looking at the problems of life of contemporary human, it seems that numerous assessments are too catastrophic, and it does not take into account the fact that progress is an essential feature of human existence. However, we are faced with the facts of irreversible transformation of life. The question is how to look at this transformation - as something positive or something negative. The dominant type of knowledge is reductive and operational. Contrary to that, Ortega y Gasset advocated an integrative approach. His thought is rooted in the European spiritual and philosophical horizon, and it draws power from the deep layers of thoughts, but at the same time, Ortega y Gasset's view of technical nature of Western civilization opens a possible new view on life. Relevant becomes Ortega y Gasset's view on vitality. With bioethical reading of Ortega's philosophy we try to find points of reference for understanding the quality of human existence that is nowadays significantly threatened by the whole range of terrifying phenomena, from the level of intervention into the genome or atom, to the level of redefining the very nature of human existence through expanding the frontiers of biological and cultural phenomena. Central is the position of the understanding of life as a whole, which implies the existence of a new type of knowledge, that knowledge which is focused on the care and conservation, where life is no longer seen as a resource, a view now traditional for Western civilization. We believe that this is one of the meanings of Ortega y Gasset's conclusion that human life is a radical reality. 


\section{References}

Gonzales, Pedro Blas (2005): Human existence as radical reality: Ortega y Gasset's philosophy of subjectivity. St. Paul: Paragon House.

Ferrater Mora, José (1957): Ortega y Gasset. An Outline of His Philosophy. New Haven: Yale University Press.

Graham, John T. (1994): A Pragmatist Philosophy of Life in Ortega y Gasset. Columbia - London: University of Missouri Press.

Gray, Rockwell (1989): The Imperative of Modernity. An Intellectual Biography of José Ortega y Gasset. Berkeley - Los Angeles: University of California Press.

Hoffmann, Thomas Sören (2015): "The Philosophical Concept of Life and Its Role in the Foundation of an Integrative Bioethics", Synthesis Philosophica 59 (1/2015), pp. 5-15.

Jurić, Hrvoje (2012): "Multi-disciplinarity, Pluri-perspectivity and Integrativity in the Science and the Education", The Holistic Approach to Environment 2 (2/2012), pp. 85-90.

Jurić, Hrvoje (2015): "From the Notion of Life to an Ethics of Life", Synthesis Philosophica $59(1 / 2015)$, pp. 33-46.

Krznar, Tomislav (2012): "Beyond Destruction: Possibility of a New Paradigm of Knowledge", The Holistic Approach to Environment 2 (1/2012), pp. 29-40.

Krznar, Tomislav (2014): "Filozofija kao briga za cjelinu - edukacijski uvidi Ortege y Gasseta" ["Philosophy as a Concern for the Whole - Educational Insights into the Philosophy of Ortega y Gasset"], in: Milinković, Jasmina; Trebješanin, Biljana (eds.): Implementacija inovacija u obrazovanju $i$ vaspitanju - izazovi i dileme [Implementation of Innovations in Education - Challenges and Dilemmas]. Beograd: Učiteljski fakultet Univerziteta u Beogradu, pp. 47-63.

Krznar, Tomislav (2015): “'Čovjek’ masa ili o ulozi filozofije u obrazovanju. Uvidi Ortege y Gasseta" ["'Mass Man' or On the Role of Philosophy in Education. Deliberation of Ortega y Gasset”], Filozofska istraživanja 140 (4/2015), pp. 645-656.

Krznar, Tomislav (2016): "Perspektiva kao definitivni bitak svijeta.Temeljni pojmovi mišljenja španjolskog filozofa Ortege y Gasseta" ["Perspective - Ultimate Reality of the World. Basic Concepts in the Philosophy of Spanish Philosopher Ortega y Gasset"], in: Čović, Ante; Jurić, Hrvoje, (eds.), Integrativno mišljenje i nova paradigma znanja [Integrative Thinking and a New Paradigm of Knowledge]. Zagreb: Hrvatsko filozofsko društvo. [in print]

Marías, Julián (1970): José Ortega y Gasset. Circumstance and Vocation. Norman: University of Oklahoma Press.

Niedermayer, Franz (1973): José Ortega y Gasset. New York: Fredrick Ungar Publishing Co.

Ortega y Gasset, José (1960): What is Philosophy. New York - London: W. W. Norton \& Company.

Ortega y Gasset, José (1961): Meditations on Quixote. New York - London: W. W. Norton \& Company.

Ortega y Gasset, José (2012): The Modern Theme. Forgotten Books.

Ouimette, Victor (1982), José Ortega y Gasset, Boston: Twayne Publishers.

Rodríguez Huéscar, Antonio (1995), José Ortega y Gasset's Metaphysical Innovation. A Critique and Overcoming of Idealism. Albany: State University of New York Press. 


\title{
Tomislav Krznar
}

\section{Prilog razumijevanju fenomena života u filozofiji Joséa Ortege y Gasseta}

\begin{abstract}
Sažetak
U ovom radu nastojimo ukazati na mogućnosti bioetičkog čitanja misli španjolskog filozofa Joséa Ortege y Gasseta. Ključni problem kojeg nastojimo izložiti Ortegino je razumijevanje fenomena života. U tom pogledu, posebno se usmjeravamo na Ortegino djelo El tema de nuestro tiempo (1923). Ortega y Gasset tvrdi da zapadnjački način mišljenja možda dovodi čovječanstvo do mentalnog kolapsa jer ne omogućuje cjelovito sagledavanje ljudskog postojanja, naglašavajući samo jednu dimenziju, onu racionalnu, i to u reduciranom pogledu. Središnja pozicija ovog rada, oblikovana kroz razumijevanje filozofije Ortege y Gasseta, razumijevanje je života kao cjeline postojanja, iz čega proizlazi imperativ izgradnje novog tip znanja, onog znanja koje je usmjereno na brigu i očuvanje. Ortega y Gasset tvrdi da je ljudski život radikalna zbilja, a bioetičko čitanje njegove misli upućuje nas na zaključak da život više ne može biti shvaćen kao resurs - kako ga poima zapadnjačka civilizacija - nego kao cjelina koju je potrebno očuvati.
\end{abstract}

Ključne riječi

José Ortega y Gasset, filozofija, život, integrativno mišljenje, bioetika

\section{Tomislav Krznar}

\section{Beitrag zum Verständnis des Phänomens des Lebens in der Philosophie José Ortega y Gassets}

\section{Zusammenfassung}

In diesem Aufsatz versuchen wir, die Möglichkeiten des bioethischen Lesens des Gedankens des spanischen Philosophen José Ortega y Gasset aufzuzeigen. Das Schlüsselproblem, das wir auszulegen versuchen, ist Ortegas Verständnis des Phänomens des Lebens. In diesem Hinblick richten wir uns in erster Linie auf Ortegas Werk El tema de nuestro tiempo (1923) aus. Ortega y Gasset argumentiert, die westliche Denkweise führe die Menschheit möglicherweise zu einem Geisteszusammenbruch, weil sie keine ganzheitliche Betrachtung der menschlichen Existenz ermögliche, indem sie nur eine Dimension, die rationale, und zwar in einer reduzierten Hinsicht betone. Die zentrale Position dieser Arbeit, aufgebaut durch das Verständnis der Philosophie Ortega y Gassets, ist das Verständnis des Lebens als Ganzheit der Existenz, woraus sich der Imperativ ergibt, eine neue Art von Wissen aufzubauen, von jenem Wissen, das Sorge und Erhaltung anstrebt. Ortega y Gasset behauptet, das menschliche Leben sei eine radikale Realität, und das bioethische Lesen seines Gedankens weist uns auf die Schlussfolgerung hin, dass das Leben nicht länger als Ressource wahrgenommen werden kann - wie es die westliche Zivilisation auffasst - sondern als die zu bewahrende Ganzheit.

Schlüsselwörter

José Ortega y Gasset, Philosophie, Leben, integratives Denken, Bioethik

\section{Tomislav Krznar}

\section{Contribution à la compréhension du phénomène de la vie chez José Ortega y Gasset}

\section{Résumé}

Dans ce travail, nous nous appliquons à montrer les possibilités d'une lecture bioéthique du philosophe espagnole José Ortega y Gasset. Le problème que l'on s'attache à exposer se rapporte à la compréhension d'Ortega du phénomène de la vie. Dans cette perspective, nous nous concentrons sur son æuvre El tema de nuestro tiempo (1923). Ortega y Gasset affirme que la manière occidentale de penser peut conduire l'humanité à un sentiment d'abattement mentale car elle ne permet pas de considérer l'existence humaine dans sa totalité, accentuant unique- 
ment une dimension, celle de la rationalité, et cela à travers un regard réducteur. La pensée centrale de ce travail, façonnée à travers la compréhension de la philosophie d'Ortega y Gasset, consiste en la compréhension de la vie en tant qu'existence totale, à partir de laquelle ressort l'impératif pour une construction d'un nouveau type de savoir, un type de savoir centré sur le soin et la sauvegarde. Ortega y Gasset affirme que la vie humaine est une réalité radicale, alors qu'une lecture bioéthique de ses pensées nous mène à la conclusion que la vie ne peut plus être comprise en tant que ressource - à la manière dont la civilisation occidentale la conçoit - mais en tant que totalité qu'il est nécessaire de préserver.

\section{Mots-clés}

Ortega y Gasset, philosophie, vie, pensée intégrative, bioéthique 